\title{
Assessment of physical workload in boiler operations
}

\author{
Rodrigues, Valéria Antônia Justino a, ${ }^{\text {, }}$, Braga, Camila Soares ${ }^{\mathrm{a}}$, Campos, Julio César Costa ${ }^{\mathrm{b}}$, Souza, \\ Amaury Paulo de ${ }^{a}$, Minette, Luciano Joséa ${ }^{a}$, Sensato, Guilherme Luciano ${ }^{a}$, Moraes, Angelo Casali de ${ }^{a}$ \\ and Silva, Emília Pio da ${ }^{a}$ \\ ${ }^{a}$ Ergonomic Laboratory - Forest Engineering Department, Federal University of Viçosa, Viçosa, MG, Brazil. \\ ${ }^{b}$ Production and Mechanical Engineering Department, Federal University of Viçosa, Viçosa, MG, Brazil.
}

\begin{abstract}
The use of boiler wood-fired is fairly common equipment utilized in steam generation for energy production in small industries. The boiler activities are considered dangerous and heavy, mainly due to risks of explosions and the lack of mechanization of the process. This study assessed the burden of physical labor that operators of boilers are subjected during the workday. Assessment of these conditions was carried out through quantitative and qualitative measurements. A heart rate monitor, a wet-bulb globe thermometer (WBGT), a tape-measure and a digital infrared camera were the instruments used to collect the quantitative data. The Nordic Questionnaire and the Painful Areas Diagram were used to relate the health problems of the boiler operator with activity. With study, was concluded that the boiler activity may cause pains in the body of intensity different, muscle fatigue and diseases due to excessive weight and the exposure to heat. The research contributed to improve the boiler operator's workplace and working conditions.
\end{abstract}

Keywords: Occupational health, thermal radiation, ergonomics

\section{Introduction}

\subsection{Use of boilers for steam generation}

The use of boilers has become very common in various sectors and industries in Brazil. The dairy industries utilize boiler wood-fired to meet energy demand in their production processes. The steam is used for pasteurization in the milk, manufacture of dairy products such as sweets, butter, cheese, etc, as well as for cleaning of the machinery and utensils.

The operation of the boiler is considered as dangerous due to the great impact and damages in cases of failure. This activity requires procedures and specifics care in the operation. It is important to stress also that this activity is considered heavy, causing damage to workers' health, for example, fatigue, body aches and problems psychological.

\subsection{Legislation of the activity in Boiler}

In Brazil, the specific regulatory standard for boilers is the NR 13 which comes to the topic "Boilers and Pressure Vessels" [19]. In this standard meet in the legal requirements for the installation, operation, maintenance and inspection of boilers, and their last update was in July 2008. The NR 13 finds legal support in level of ordinary legislation, in Articles 187 and 188 of the Consolidation of Labor Laws - CLT $[5]$.

\subsection{Main risks of the activity in boilers}

The utilizing of boiler implies various types of accidents such as burns, injuries, fires and explosions, among others. Among these, the risk of explosions is considered very important, for to be present at all

\footnotetext{
* Corresponding author. Rua Conselheiro Lafaiete, n. 403, Bairro Elisa Leonel, Piumhi-MG, CEP: 37925-000. Tel:031-9336-5918. E-mail: valeriaufv2001@yahoo.com.br
} 
times of operation, being its continuous control [21]. Most accidents occur due to lack of operating procedures and operator inattention to devices at alerts that inform possible mechanical problems and errors human during operation. The heavy activity and exposure to excessive heat is another important factor for the occurrence of failures and the risk of accidents during the operation in boilers, since fatigue impair the ability to work and increases the lack of attention.

\subsection{Heart rate}

The functioning the system cardiovascular for spent the energy during realizing at work varies according with the type of work (static or dynamic), beyond the number of muscles involved in the activity [7]. Several studies show that at the beginning of the work, the heart rate increases progressively, but quickly stabilize into activities that do not require effort accented, but when the workload is intense, the heart rate continues increasing and may lead to death of the worker.

The increase in heart rate of the operator, exposed excessive heat, occurs due the heat exchanges between the body and the environment [12]. In this situation, the heart increases the blood pumping to maintain body temperature around $37{ }^{\circ} \mathrm{C}$, and too pump blood to the muscles that are activity during in the work [9].

In Places with temperature high, the human body loses water by skin (sweat). During sweating, part of the water released through sweating comes from the plasma, and can occur loss up to $18 \%$ the plasma content [6]. This reduction in blood volume, combined with peripheral vasodilation, reduces venous return with consequent increase in heart rate, for maintain cardiac output [10].

The cardiac efficiency stay compromised, since the hypohydration and heat and/or absorbed by the body limit the transportation and availability of oxygen in the body. These effects are harmful to the human, as well as, to the mechanism of thermoregulation $[10,15]$.

\subsection{Influence of thermal overload in the human body}

A thermal overload is defined as the amount of energy the organism must dissipate heat to reach equilibrium thermic. This energy is the combination of metabolic heat and heat resulting in the physical activity. According to Alexandre [15] for the heat balance be maintained, the metabolic heat must be dissi- pated. The regulation of the temperature inside the body is accomplished through fluid evaporation by the skin and peripheral vasodilation $[4,22]$.

The mechanisms of self regulation, to maintain internal body temperature around $37{ }^{\circ} \mathrm{C}$ independent from external temperature [18]. However, values much lower or higher may affect cellular metabolism, causing diseases in the human organism.

According to Roberto [13], when a room temperature is higher at $36{ }^{\circ} \mathrm{C}$, the unique mechanism of the heat loss is evaporation. At loss of heat by evaporation the liquid through by skin, dissipates heat in the rate $0.58 \mathrm{Kcal}$ for each $\mathrm{g}$ of liquid evaporated [3].

The volume at liquid required to dissipate this amount of heat can result in great loss electrolytes present in the human body.

If the mechanisms of self-regulation are not sufficient to maintain the internal temperature of the body consequences dangerous for the organism as, dehydration, cramps, loss of the consciousness, thermal shock, can happen [17].

The losses by water from the body cause the process dehydration. The influence this process in the mechanisms of thermoregulation is a factor determinant for the fatigue occurrence. Hugo [1] adds that work in adverse weather conditions produces physical and nervous exhaustion, reducing capacity.

To minimize the harmful effects of thermal overload, it can be introduced rest breaks during the work turn and mineral reposition of isotonic liquid.

\subsection{Physical workload}

The raw material most commonly used for boiler feed is the wood and normally this stage is realized manually, involving loading of logs, which can weigh up to $50 \mathrm{~kg}$. The lack of mechanization in the feeding process makes heavy activity and causes physical fatigue of the operator. According to Eduarda [11], the heavy work involves great physical effort, high energy consumption and cardiovascular and lungs burdening.

The physical work load is also changed by working posture and by the person's physical condition [8]. The combination of excess weight with thermal overload intensifies the damage to health. According to Edilson [20], the heart is prompted both by physical exertion, as the regulation of internal temperature.

The purpose of this study was to evaluate the physical workload of boilers operators that exercise activities manually in boilers (overweight) in place 
with exposure in high temperatures (heat excessive) during the workday.

\section{Method}

\subsection{Location and study population}

The study was conducted in a boiler, MML brand, model 625 , year of manufacture 1995, flamotubular type, category B, with a capacity of $1200 \mathrm{~kg} \cdot \mathrm{h}^{-1}$ and maximum working pressure of the $8.5 \mathrm{kgf.cm}{ }^{-2}$. This model has exhaustion a system located at the rear in the boiler, which contributes decrease to thermal exposure of the operator during the workday. The population sampled was the operators of the boiler.

\subsection{Equipment used}

Were used for collection at sample: a heart rate monitor, Garmin brand, Forerunner 305 model, a digital chronometer, Oregon Scientific brand, SL 928M model, a wet-bulb globe thermometer (WBGT), "Politeste Instrumentos" brand, MPG0 model, a tape-measure and a digital infrared camera.

\subsection{Evaluation of physical workload}

The physical work load assessment was based on the methodologies in literature. Was Utilized the Nordic Questionnaire of musculoskeletal symptoms, the Diagram of Painful Areas and the rate heart of the operators. Was assessed too the place of higher thermal overload and biophysical profile of the operators.

\subsubsection{Biophysical profile of the operators}

We collected the information: of age, weight and height to calculated Body Mass Index (BMI) utilizing to Eq. (1).

$$
\mathrm{BMP}=\mathrm{P} /(\mathrm{H})^{2} \quad \text { Eq. }(1)
$$

Where:

$\mathrm{BMI}=$ body mass Index $\left(\mathrm{kg} \cdot \mathrm{m}^{-2}\right) ; \mathrm{P}=$ body mass $(\mathrm{kg})$ and $\mathrm{H}=$ height (m).

The BMI values were evaluated according to the Table 1, proposal by the ministry of the World Health Organization [22].
Table 1

Classification of Body Mass Index (BMI) for adults

\begin{tabular}{ll}
\hline Classification & BMI $\left(\mathrm{kg} . \mathrm{m}^{-2}\right)$ \\
\hline Low weight & $<18.5$ \\
Normal & $18.5-24.9$ \\
Overweigh & 25 or greater \\
Pre-Obese & $25-29.9$ \\
Obese I & $30-34.9$ \\
Obese II & $35-39.9$ \\
Obese III & 40 or greater \\
\hline
\end{tabular}

\subsubsection{Nordic Questionnaire}

Was used a diagram of the human body divided into nine parts (neck, shoulders, elbows, wrists/hands, dorsal spine, lumbar spine, thighs, knees and ankles/feet). The workers responded 'yes' or 'no' to the occurrence of pain in these parts in the body after seven days work without absenteeism. Was questioned also the occurrence of absenteeism from work during working lives due to the problem identified by the operator in the diagram.

\subsubsection{Painful Areas Diagram}

Was used a diagram of the human body divided in twenty-four segments (right and left side). The workers at the end of the working day indicated the regions painful. Then they evaluated subjectively the degree of discomfort in each of the 24 segments, using a scale from zero to seven, ranging from "comfortable extremely" the "extremely uncomfortable".

\subsubsection{Heart rate}

The beats the heart were collected with the aid of a heart rate meter. The equipment consists of three parts: a digital pulse receiver, a transmitter and a elastic strap with electrodes. The transmitter is fixed in the operator's chest, and the beats the heart are captured and stored in the wrist receiver. The data stored in the meter of heart rate were downloaded into a computer using software developed by manufacturers for this purpose.

For analysis conditions overload in the working were used Eqs. (2) and (3) proposed by Elías [16].

$$
\mathrm{CCV}=(\mathrm{FCT}-\mathrm{FCR}) * 100 /(\mathrm{FCM}-\mathrm{FCR}) \mathrm{Eq} .(2)
$$

Where:

CCV cardiovascular load (\%); FCT = average working heart rate $(\mathrm{bpm}) ; \mathrm{FCM}=$ maximum heart rate $(220$ - age) and FCR = resting heart rate (bpm). 


$$
\mathrm{FCL}=0.40 *(\mathrm{FCM}-\mathrm{FCR})+\mathrm{FCR} \quad \text { Eq.(3) }
$$

Where:

$\mathrm{FCL}=$ heart rate limit (bpm); $\mathrm{FCM}=$ maximum heart rate $(220-$ age $)$ and $\mathrm{FCR}=$ resting heart rate $(\mathrm{bpm})$.

According to Elías [16], when the cardiovascular load exceeds $40 \%$, the pause time (pause) necessary must be determined, using Eq. (4), and the work time reorganized.

$$
\mathrm{Tr}=\mathrm{Ht} *(\mathrm{FCT}-\mathrm{FCL}) /(\mathrm{FCT}-\mathrm{FCR})
$$

Where:

$\mathrm{Tr}=$ time of pause (minutes); $\mathrm{Ht}=$ duration of labor (minutes); FCT $=$ average working heart rate (bpm); $\mathrm{FCR}=$ resting heart rate $(\mathrm{bpm})$ and $\mathrm{FCL}=$ heart rate limit (bpm).

\subsubsection{Place of higher thermal overload}

Was used a tape measure to mark the main points where the operator remained during boiler operation. At these points, and at the rest area and were determined the WBGT Index. Was used the Tukey test at $5 \%$ significance level to find the place of exposure greatest thermic compared to the rest area. In the point chosen was made the register photographic of the area with higher incidence of thermal radiation in the operator's body, using infrared digital camera.

\section{Results and discussion}

\subsection{Description of desktop}

The working pressure utilized by the operators is at most $7 \mathrm{kgf.cm}{ }^{-2}$, operational reasons. The metallic structure of the boiler presents signs of corrosion. According to the operators, was not realized safety inspection since the installation of the boiler. In Figure 1 is showed the boiler.

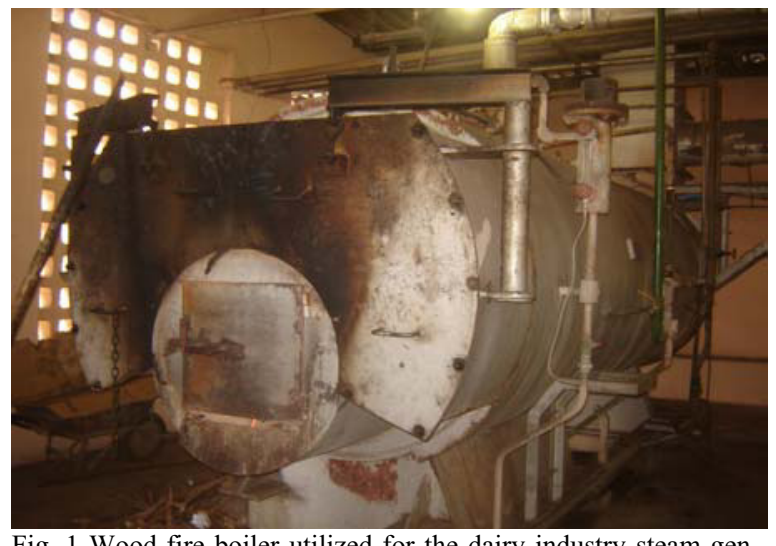

Fig. 1 Wood-fire boiler utilized for the dairy industry steam generation.

The fuel material used in the boiler is wood. The wood transported by a truck, stored in the courtyard until the time of withdrawal by the operators in a wheelbarrow. In Figure 2 is showed the wood stored in the courtyard in the boiler house and the wood transported by operator.

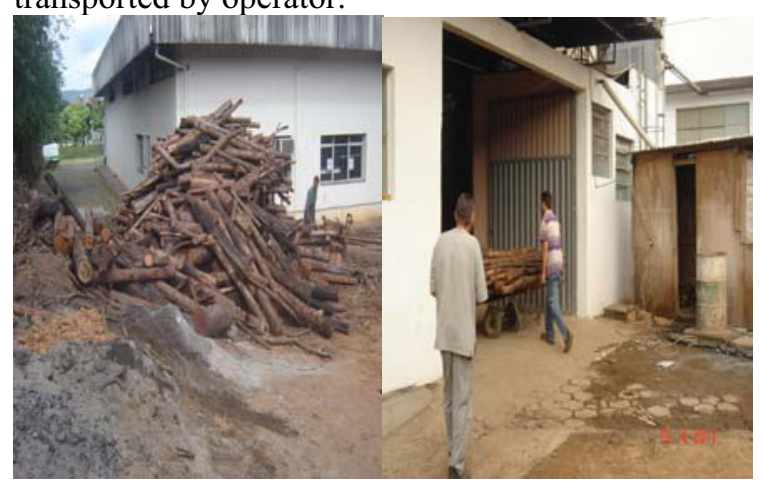

Fig. 2 Wood stored in the courtyard of the boiler house and being transported by the operator.

The ashes from the combustion are stored at the bottom of the boiler near the furnace. This configuration exposes the operator to particulate matter and soot. It is necessary the utilization of a mask, especially, during the cleaning the ashtray. The boiler was built inside the boiler house and does not receive from sunlight. The environment has a little ventilation and receives full time artificial lighting. During the activity, the operator is subjected to high temperatures, especially during the recharge the wood in the furnace the boiler. In Figure 3 is shown the boiler in full operation the night shift, with the door open after feeding. 


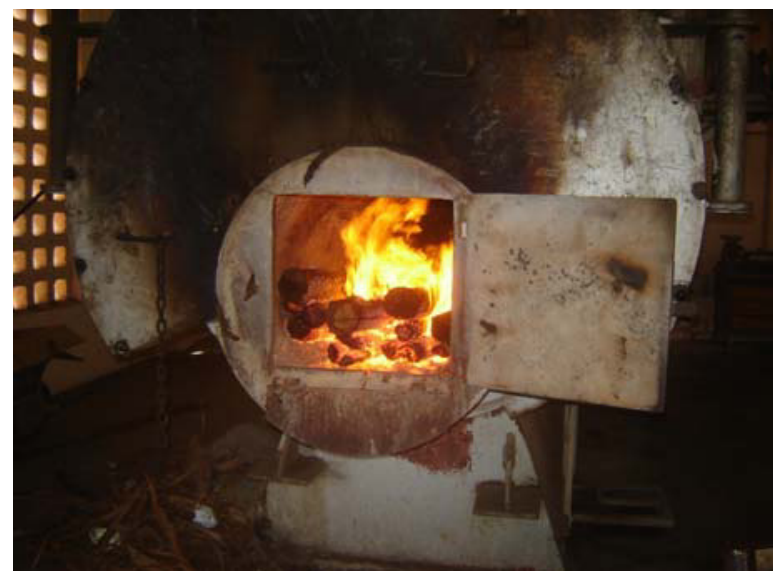

Fig. 3 Boiler in full operation during the night shift.

The house the boilers, has not outputs on opposite sides. This situation, according to a regulating norm $\mathrm{n}^{\mathrm{o}} 13$ (NR 13), is an unconformity, beyond hindering the exit of people in emergencies.

\subsection{Profile of operators}

The sector in the boiler has four operators, all male and right-handed. The majority of operators are in the range obesity; this situation overloads most the heart during the workday. Another factor that interferes with the physical capacity is the sedentary, since none of the operators practice physical activity. In the Table 2 is showed data at age, weight, height and classification in relation Body Mass Index the operators.

Table 2

Biophysical profile of boiler operators

\begin{tabular}{lllll}
\hline \multirow{2}{*}{$\begin{array}{l}\text { Biophysical } \\
\text { profile }\end{array}$} & \multicolumn{4}{l}{ Boiler operators } \\
\cline { 2 - 5 } & 1 & 2 & 3 & 4 \\
\hline Age & 45 & 43 & 60 & 28 \\
Weight $(\mathrm{Kg})$ & 82 & 79 & 80 & 75 \\
Height $(\mathrm{m})$ & 1.76 & 1.68 & 1.72 & 1.79 \\
BMI & 26,5 & 28 & 27 & 23,4 \\
\multirow{2}{*}{ Classification } & Pre- & Pre- & Pre- & Normal \\
& Obese & Obese & Obese & \\
\hline
\end{tabular}

\subsection{Nordic Questionnaire (QN)}

The analyses of data obtained with the application of $\mathrm{QN}$, enabled assess of potential areas for the occurrence of musculoskeletal injuries resulting from physical exertion during work. In Figure 4 are shown the occurrence percentage and the areas with pain or discomfort in the last seven days.

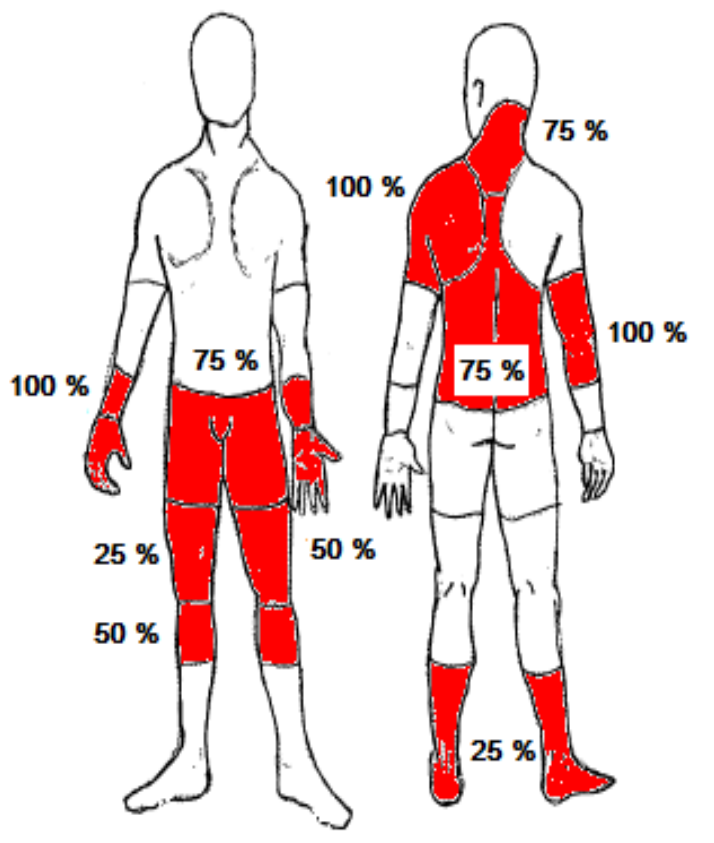

Fig. 4 Identification of areas of occurrence with pain/discomfort of operators based on the Nordic Questionnaire.

As illustrated in figure 4 , the main regions with pain/discomfort were the left shoulder, right elbow, wrists, neck, back (upper and lower), hips, thighs, knees at them, ankles and feet. The pain/discomfort is related, possibly, with physical effort of the operator during the transport of logs from the patio to the storage site near the boiler, and during feeding process in the boiler. Although there have been many complaints, the operators never strayed from the work activity because of pain reported. Figure 5 shows the stage of feeding the boiler.

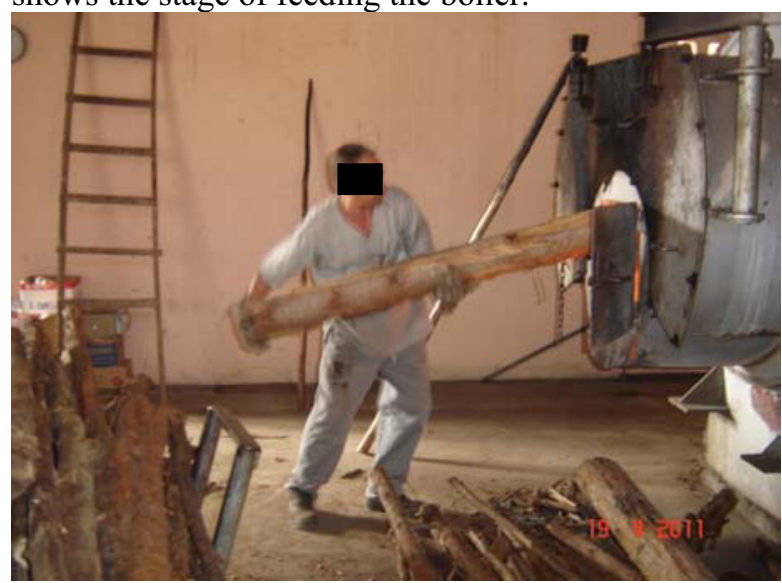

Fig. 5 Physical sharp exertion by operator during the step of feeding the boiler. 


\subsection{Diagram of Painful Areas (DPA)}

The analysis of data obtained with the DPA, enabled the knowledge of the degree of nuisance and localization more precise the place of the body, since this methodology uses a diagram with more divisions of the human body. In the Table 3, are presented in the results degree of discomfort for each of the body parts of the operators.

Table 3

Degree of discomfort in the parts the body the operator's the boiler

\begin{tabular}{|c|c|c|c|c|c|}
\hline \multirow{2}{*}{ Side } & \multirow{2}{*}{ Body Part } & \multicolumn{4}{|c|}{ Boiler operators } \\
\hline & & 1 & 2 & 3 & 4 \\
\hline \multirow{12}{*}{ Right } & Shoulder & 5 & 4 & 3 & 5 \\
\hline & Arm & 4 & 5 & 5 & 4 \\
\hline & Fore arm & 6 & 6 & 6 & 6 \\
\hline & Hand & 6 & 6 & 6 & 6 \\
\hline & Neck & 5 & 6 & 6 & 6 \\
\hline & Back top & 6 & 6 & 5 & 6 \\
\hline & Back medium & 6 & 5 & 5 & 5 \\
\hline & Back lower & 5 & 5 & 5 & 6 \\
\hline & Hip & 5 & 5 & 5 & 5 \\
\hline & Thigh & 4 & 5 & 5 & 6 \\
\hline & Leg & 4 & 4 & 5 & 5 \\
\hline & Foot & 3 & 4 & 4 & 4 \\
\hline \multirow{12}{*}{ Left } & Shoulder & 6 & 6 & 5 & 6 \\
\hline & Arm & 3 & 2 & 5 & 3 \\
\hline & Fore arm & 4 & 5 & 5 & 6 \\
\hline & Hand & 6 & 6 & 6 & 6 \\
\hline & Neck & 5 & 6 & 6 & 6 \\
\hline & Back top & 6 & 6 & 5 & 6 \\
\hline & Back medium & 6 & 5 & 5 & 5 \\
\hline & Back lower & 5 & 5 & 5 & 6 \\
\hline & Hip & 4 & 4 & 5 & 5 \\
\hline & Thigh & 4 & 4 & 4 & 4 \\
\hline & Leg & 3 & 3 & 3 & 3 \\
\hline & Foot & 4 & 4 & 4 & 4 \\
\hline
\end{tabular}

The greatest discomfort was degree 6 . The parts in the body, reported by most the operators, with greater degree discomfort were fore arm, right arm, right hand, neck, upper back. However, it was not observed any area without discomfort. The Article 198 of section XIV, about the prevention of fatigue, Chapter V of the Consolidation of Labor Laws, reports that the maximum weight that an employee can remove individual is $60 \mathrm{~kg}$ in the activities of lifting and carrying load [2]. This is applied to male workers, in the case of women and children there are other specifications. Even with the statutory provision, the load capacity vary from person to person the same sex, and not must be required nor permitted the manual transport of loads per employee, whose weight compromise their health or safety.

\subsection{Cardiovascular workload}

The resting heart rate was 74, 76, 82 and $70 \mathrm{bpm}$ for the operators $1,2,3$ and 4 , respectively. In the Table 4 are presents the results of cardiovascular load (CCV) and the heart rate limit (FCL) for the operators.

Table 4

Results of heart rate the boiler operators

\begin{tabular}{lllll}
\hline \multirow{2}{*}{ Heart rate } & \multicolumn{3}{l}{ Boiler operators } \\
\cline { 2 - 5 } & 1 & 2 & 3 & 4 \\
\hline FCT $(\mathrm{bpm})$ & 127 & 132 & 138 & 115 \\
FCM $(\mathrm{bpm})$ & 177 & 175 & 160 & 192 \\
CCV $(\%)$ & 51.5 & 56.6 & 71.8 & 34.7 \\
FCL $(\mathrm{bpm})$ & 115 & 116 & 113 & 121 \\
\hline
\end{tabular}

The cardiovascular load exceeded $40 \%$ for the three operators. Thus, is precise calculate the time of rest for the operators, using the equation 4 . The resting time was 90, 140 and 190 minutes for operators 1 , 2 and 3, respectively. According to Table 5, the activity was considered heavy.

Table 5

Rating of the workload based on heart rate

\begin{tabular}{ll}
\hline Physical work load & Average heart rate $(\mathrm{bpm})$ \\
\hline Very light & $\leq 75$ \\
Light & $76-100$ \\
Moderately heavy & $101-125$ \\
Heavy & $126-150$ \\
Very heavy & $151-175$ \\
Extremely heavy & $>175$ \\
\hline \multicolumn{2}{c}{ Source: Christensen, cited by Elías [16]. }
\end{tabular}

\subsection{Place of higher thermal exposure}

The distances that the operator stayed of the boiler were $0.3 \mathrm{~m}, 1 \mathrm{~m}, 2 \mathrm{~m}$. In the Table 6 is showed, the test to comparison of means (Tukey test) for the WBGT Index, in the three distances considered and in the resting place. The limit established for WBGT Index in the regulatory norm NR 15 , for continuous work, in activities heavy is $25^{\circ} \mathrm{C}$ [3].

Table 6

Result of comparison test of means (Tukey test)

\begin{tabular}{llll}
\hline \multirow{2}{*}{ Place } & \multicolumn{3}{l}{ Shift work } \\
\cline { 2 - 4 } & Morning & Afternoon & Evening \\
\hline $0.3 \mathrm{~m}$ & $32.6 \mathrm{a}$ & $34.1 \mathrm{a}$ & $30.8 \mathrm{a}$ \\
$1 \mathrm{~m}$ & $28.4 \mathrm{ab}$ & $29.4 \mathrm{~b}$ & $27.4 \mathrm{ab}$ \\
$2 \mathrm{~m}$ & $25.7 \mathrm{~b}$ & $26.6 \mathrm{~b}$ & $24.6 \mathrm{~b}$ \\
Pause & $17.7 \mathrm{~cd}$ & $17.6 \mathrm{~cd}$ & $17.3 \mathrm{c}$ \\
\hline \multicolumn{4}{c}{ GL $=2, \alpha=5 \%$}
\end{tabular}


It is observed by results, that only in the distance of $2 \mathrm{~m}$ operator in relation to boiler, the night shift, was below limit WBGT Index. The distance with greater exposure the operator was of $0.3 \mathrm{~m}$ from the boiler during the period the afternoon. In this position and period of the work was made the register photographic the radiation thermic that the operator stayed exposed. In the Figure 6 is showed the thermic radiation that operator was exposed in the feed of the boiler.

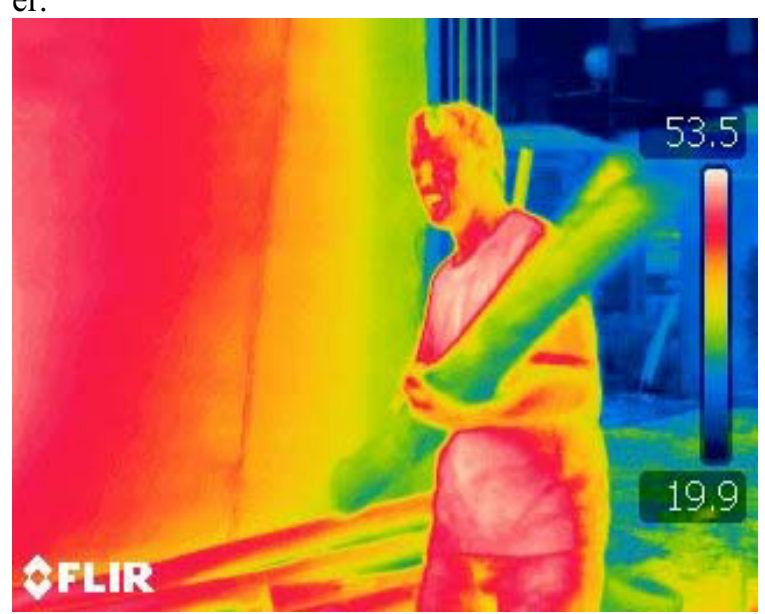

Fig. 6 Photography infrared in the operator during feeding the boiler.

The infrared photograph shows the energy as heat and its distribution. The color red indicates areas with greater intensity of heat, while the blue areas show the areas with less intensity. By the digital image we can see that part the front of the operator stayed totally red, this is high intensity radiant energy. It is noteworthy that in the region of the abdomen are located vital organs. The continue exposure can compromise functioning of these organ and may cause damage the health of the operator. In addition, prolonged exposure to thermal radiation can cause several other humans health problems.

\section{Conclusions}

The study, concluded that the activity causes pains with intensity different in the body due to excessive loading of weight and exposure to heat, that cause muscle fatigue and cause diseases, like cancer. The work of feeding the boiler requires a great physical effort, because is necessary, to lift logs of Wood of different sizes and weights. At this stage, it was observed that the operator carries out activities with improperly posture, causing pain, especially in the lumbar region. With the study, it was concluded that operator's age and time influenced the ability to concentrate and to perform the function. The photographic records showed that the greatest incidence of thermal radiation was in the thoracic region of the body. None operator, used the apron to protect the chest area. The exposure to excessive heat and the work heavy caused great changes in operator heart rate, mainly in the older professionals. It was recommended the use of personal protective equipment (PPE), as boots, apron and leather gloves and when handling ash suggests the use of masks and safety glasses due to the presence of particulate materials. One way to reduce the physical effort could be the use of conveyor belts for driving the wood logs to the entrance of the furnace of boiler. It was important that operators received the proper PPE to perform the function, as well as training to use them. The activity should be made with more than one operator per shift to prevent weight overload. The workload must be compatible with age and with physical structure of the operator.

\section{Acknowledgements}

The authors acknowledge the FAPEMIG Fundação de Amparo à Pesquisa do Estado de Minas Gerais and the $\mathrm{CNPq}$ - Conselho Nacional de Desenvolvimento Científico e Tecnológico for financial assistance.

\section{References}

[1] A. C. Hugo. Temas de saúde ocupacional: coletânea dos trabalhos da Ergo. Belo Horizonte: Ergo; 1987. 250 p.

[2] A. J. Young. Energy substrate utilization during exercise in extreme environments. Exercise and Sports Reviews, v. 18, p. 65-117, 1990.

[3] B. Cherie, M. Allen, B. Kevin Understanding How the Body Regulates Heat. N.C. Department of Labor Occupational Safety and Health Program. Disponível em: http://www.nclabor.com/osha/etta/indguide/ig35.pdf. Acessado em: 22/09/2011.

[4] C. B. Andréa, C. R. Michelline, C. S. Antônio, S. C. Luiz. Impacto do conforto térmico nos profissionais de saúde no CTI de um hospital de João Pessoa. Revista Conf. Eficiência Segurança do Trabalho, v. 1, n. 1, 2004.

[5] CLT - Consolidações das Leis Trabalhistas - Capítulo V - da segurança e medicina do trabalho - Seção XII - das caldeiras, fornos e recipientes sob pressão - art. 187 e 188 - Redação conforme a Lei $\mathrm{n}^{0}$ 6.514, de 22.12.1977. Disponível em: http://www.cpact.embrapa.br/cipa/pdf/clt.pdf. Acessado em: 07 de agosto. 2011. 
[6] C. V. Gisolfi, C. B. Wenger. Temperature regulation during exercise: old concepts, new ideas. Exercise and Sports Science Reviews, v. 12, p. 330-371, 1984.

[7] F. C. Nilton, S. P. Amaury, T. C. G. Antônio, M. J. Luciano, M. C. Carlos. Avaliação da carga física de trabalho exigida em operações de colheita florestal. Revista Árvore, Viçosa-MG, v. 22, p. 535-543, 1998.

[8] G. B. M. Lia, P. Paulo, K. F. Silvério. Avaliação Quantitativa da Carga Física de Trabalho integrada com a Ergonomia Participativa em Setores de uma Fundição. In: Encontro Nacional de Engenharia de Produção, Ouro Preto, 2003. Anais... Ouro Preto: ABREPO, 2003. 1 CD.

[9] G. Etienne. Manual de Ergonomia: adaptando o trabalho ao homem. 5. ed. Porto Alegre: Bookman, 2005.

[10]H. M. Emily and W. L Christine. Environment and human performance. Champaing, Human Kinetics, 1986.

[11]H. T. Eduarda, P. Mônica, R. R. Lívia, A. G. Fernando Operadores de caldeira à lenha e carga de trabalho. IJIE Revista Iberoamericana de Engenharia Industrial. Florianópolis-SC, v.1, n. 2, p. 61-75, 2009.

[12]L. Antoine. Ergonomia. São Paulo: Epu, 1977.

[13]L. Roberto and X. A. P. Antônio Conforto térmico e stress térmico. UFSC/Lab. EEE, 2002 (apostila).

[14]MINISTÉRIO DO TRABALHO E EMPREGO. Portaria ${ }^{\circ}$ 3214 de 8 de junho de 1978: Normas Regulamentadoras de segurança e saúde do trabalho. In: Manual de Legislação Atlas de Segurança e Medicina do Trabalho, $65^{\mathrm{a}}$ edição, São Paulo, Atlas, $2010.747 \mathrm{p}$.

[15]R. R. Alexandre. Sistema de ventilação, resfriamento e redução de calor. Disponível em: http://www.segurancaetrabalho.com.br Acessado em: 15 de agosto. 2011

[16]S. A. Elías . Temas de ergonomia aplicados al aumento de la productividad de la mano de obra en cosecha florestal. In: Simpósio brasileiro sobre colheita e transporte florestal, Vitória, 1997. Anais... Vitória: SIF/DEF, 1997, p. 46-60.

[17]S. G. Emerson. Problematyka termoregulacji w sporcie. In: International conference "atlanta 96: direction of training optimization. Spala, Polonia, 1994. Keynote lecture. Spala, 1994

[18] S. Marlusa and A. C. D. Gilberto. Saúde física do trabalhador rural submetido a ruídos e à carga térmica: um estudo em operadores de tratores. O Mundo da Saúde, São Paulo, v. 32, n. 3, p. 275-286, 2008.

[19] S. M. Tuffi. Manual prático de avaliação e controle de calor: PPRA. São Paulo: Ltr; 2000, 71 p.SANTOS, N. dos. Análise ergonômica do trabalho. UFSC/PPGEP, 1991(Apostila).

[20]S. R. Edilson. Uma contribuição à reformulação da norma regulamentadora 13 (NR-13) na perspectiva da adoção de sistema de gestão de segurança e saúde ocupacional. 2008. 75 f. Dissertação (Mestrado em Ciências em Engenharia de Produção) - Centro de Tecnologia Programa de Engenharia de Produção. Universidade Federal do Rio Grande do Norte, Natal, 2008.

[21]V. G. A. Rodolfo, M. Maria Elizabeth, M. C. Luiz. Trabalhadores da saúde sob risco: o uso de pulverizadores no controle de vetores. Revista Produção, v. 15, n. 2, p. 263-272, 2005.

[22] WHO - World Health Organization. Physical status: the use and interpretation of antrometry: report of a WHO expert committe. WHO Technical Report Series. 